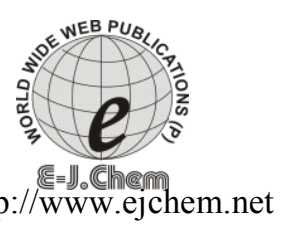

ISSN: 0973-4945; CODEN ECJHAO

E-Journal of Chemistry

2012, 9(4), 1911-1918

\title{
Synthesis, Chacterization, and Thermal Study of Terpolymeric Resin Derived from m-cresol, Hexamine and Formaldehyde
}

\author{
K. M. KHEDKAR ${ }^{1}$, V. V. HIWASE ${ }^{2}$, A. B. KALAMBE $^{1}$, AND S. D. DEOSARKAR ${ }^{3}$ \\ ${ }^{1}$ Institute of Science, R. T. Road, Nagpur-440 010 (MS) India \\ ${ }^{2}$ Arts, Commerce and Science College, Arvi, Wardha (MS) India \\ ${ }^{3}$ Swami Ramanand Teerth Marathwada University Nanded-431 606 (MS) India \\ vvhiwase@gmail.com
}

Received 17 November 2011; Accepted 15 January 2012

\begin{abstract}
Terpolymeric resin was prepared from m-cresol (0.1M), hexamine $(0.05 \mathrm{M})$ and formaldehyde $(0.2 \mathrm{M})$ by acid catalyzed polycondensation method using $1 \mathrm{M} \mathrm{HCl}$ in temperature range of $122-130^{\circ} \mathrm{C}$. The resin was abbreviated as m-CHF-I. The molecular weight of terpolymer was determined by non-aqueous conductometric titration technique. The structure of resin was determined by its elemental analysis, UV-VIS, IR, and NMR data. The thermokinetic parameters were determined using Freeman-Carroll (FC) and Sharp Wentworth (SW) method in temperature range (410$\left.485^{\circ} \mathrm{C}\right)$. The values of activation energies (Ea), entropy $(\Delta \mathrm{S})$, and free energies $(\Delta \mathrm{G})$ were in good agreement. The order of degradation reaction determined by FC method was confirmed by SW method.
\end{abstract}

Keywords: terpolymer, TGA, polycondensation, resin, thermal analysis.

\section{Introduction}

In recent years, considerable interest has been shown in the synthesis and study of chelating resins containing resin with Nitrogen, Sulphur and Oxygen donar atoms on polymeric interface. These polymeric resins, nowadays, have been received much attention and importance, only due to their wide range industrial application. The terpolymers can be used as adhesive, retardants, surface coating, dyes, fungicides in plants and living tissues, ion exchangers, semiconductors, rectifiers, rechargeable electrical cells etc. Thermally stable polymer recently become boon to polymer chemist due to applicability at elevated temperature beside challenges that have to face owing to thermal instability and low processability. In this connection many co-worker tried to improve the thermal stability by changing the monomer composition in polymer synthesis ${ }^{1-9}$. 
Thermogravimetric study of polymer provides information about the degradation pattern during heating and thermal stability. Phenolic resins have a large number of practical applications in electronic controls, insulating materials, aerospace industry, machine parts etc. because of their high thermal stability, chemical and heat resistance ${ }^{10}$.

Hiwase $e a^{11}$ have reported thermokinetic parameters of resin derived from p-hydroxy benzaldehyde, resorcinol and formaldehyde.

Gurnule et $a l^{12}$ have reported thermodynamic parameters and order of thermal stabilities of tercopolymers by using TGA. Aswar et $a l^{13}$ have reported the sequences of thermal stability of polymeric chelates predicted on the basis of decomposition temperatures and activation energy was found to be $\mathrm{Ni}>\mathrm{Mn}>\mathrm{Cu}>\mathrm{Co}>\mathrm{Zn}$. Whereas kinetic and thermodynamic parameters were calculated from dynamic TGA by the use of Sharp-Wentworth and Freeman-Carroll methods. Masram et $a l^{14}$ reported kinetic study of thermal degradation of resin derived from salicylaldehyde, ethylenediamine and formaldehyde. methods.

In present work thermokinetic parameters were determined by using following

\section{A) Freeman-Carroll Method (FC):}

In this the kinetic parameters determined by following expression, ${ }^{15-16}$

$$
\frac{\Delta \log (d w / d t)}{\Delta \log W_{r}}=\left[-\frac{E a}{2.303 R}\right] \times \frac{\Delta(1 / T)}{\Delta \log W_{r}}+n
$$

where $\mathrm{dw} / \mathrm{dt}=$ Rate of change of weight with time, $\mathrm{W}_{\mathrm{r}}=$ difference between weight loss at completion of reaction, and at time t., Ea $=$ activation energy, $\mathrm{n}=$ order of reaction

B) Sharp-Wentworth Method (SW):

Following expression is used to evaluate the kinetic parameters, ${ }^{17-19}$

$$
\log \frac{(d \alpha / d t)}{(1-\alpha)^{n}}=\log \frac{A}{\beta}-\frac{E a}{2.303 R T}
$$

where $\mathrm{d} \alpha / \mathrm{dt}$ is fraction of weight loss with time, $\mathrm{n}$ is the order of reaction, $\mathrm{A}$ is frequency factor, $\beta$ is linear heating rate, and $\alpha$ is the fraction of amount of reactant.

\section{Preparation of $m-C H F-I$}

A mixture of m-cresol $(0.1 \mathrm{M})$, hexamine $(0.05 \mathrm{M})$ and formaldehyde $(0.2 \mathrm{M})$ with $1 \mathrm{M} \mathrm{HCl}$ was refluxed over oil bath at $122-130^{\circ} \mathrm{C}$ for $6 \mathrm{hrs}$ with stirring. The solid product so obtained was immediately removed from the flask as soon as the reaction period was over. It was washed with hot water, dried and powdered. The powder was repeatedly washed with hot water to remove unreacted monomers. The air dried product was extracted with ether to remove copolymer which might be present along with the terpolymer. It was dissolved in $1 \mathrm{M} \mathrm{NaOH}$ and reprecipitated using $1: 1 \mathrm{HCl}$ solution. The product finally collected by filtration, washed with hot water dried, powdered and kept in vacuum. The yield was found to be $74 \%$. The synthetic details are shown in Table 1 . 
Table 1: Synthetic details of m-CHF-I.

\begin{tabular}{|l|c|}
\hline parameters/conditions & specifications \\
\hline Terpolymeric resin & m-CHF-I \\
\hline m-Cresol & $0.1 \mathrm{M}$ \\
\hline Hexamine & $0.05 \mathrm{M}$ \\
\hline Formaldehyde & $0.2 \mathrm{M}$ \\
\hline Catalyst, 1 M HCl & $100 \mathrm{~mL}$ \\
\hline Temperature & $122-130^{\circ} \mathrm{C}$ \\
\hline Time & $6.0 \mathrm{hrs}$ \\
\hline Yield & $74 \%$ \\
\hline
\end{tabular}

\section{Result and Discussion}

Elemental Analysis:

The terpolymeric resin was analyzed for carbon, hydrogen, nitrogen and oxygen content. The elemental analysis was carried out at Sophisticated Analytical Instrumental Facility (SAIF) Punjab University, Chandigarh. The details of elemental analysis are incorporated in Table 2.

The number average molecular weight of m-CHF-I terpolymer has been determined by conductometric titration method in non-aqueous medium and using standard potassium hydroxide $(0.1 \mathrm{M})$ in absolute ethanol as a titrant. The conductance versus milliequivalent (Meq.) of $\mathrm{KOH}$ per $100 \mathrm{~g}$ of resin was plotted. The large numbers of breaks were observed in the plot. The average degree of polymerisation and hence the number average molecular weight of terpolymer have been determined using the following relations ${ }^{20-25}$.

\section{$\overline{D P}=\frac{\text { Milliequivalent of base required for complete neutralisation }}{\text { Milliequivalentof base required for smallest interval }}$}

\section{$\overline{M n}=\overline{D P} \times$ molecular weight of repeat unit}

The molecular weight of repeat unit was calculated using elemental analysis data as shown in Table 2. The average degree of polymerisation and number average molecular weight of terpolymer resin were found to be 15.0 and 5160 respectively.

Table 2: Elemental Analysis of m-CHF-I.

\begin{tabular}{|c|l|l|l|l|l|}
\hline $\begin{array}{l}\text { \%C Found } \\
\text { (Calc.) }\end{array}$ & $\begin{array}{l}\text { \%H Found } \\
\text { (Calc.) }\end{array}$ & $\begin{array}{l}\text { \%N Found } \\
\text { (Calc.) }\end{array}$ & $\begin{array}{l}\text { \%O Found } \\
\text { (Calc.) }\end{array}$ & $\begin{array}{l}\text { empirical } \\
\text { formula of } \\
\text { repeat unit }\end{array}$ & $\begin{array}{l}\text { Molecular } \\
\text { weight of } \\
\text { repeating } \\
\text { unit }\end{array}$ \\
\hline $\begin{array}{c}69.81 \\
(69.76)\end{array}$ & $\begin{array}{c}7.23 \\
(7.55)\end{array}$ & $4.17(4.06)$ & $\begin{array}{l}18.79 \\
(18.63)\end{array}$ & $\mathrm{C}_{20} \mathrm{H}_{16} \mathrm{NO}_{4}$ & 344 \\
\hline
\end{tabular}

\section{UV-VIS Spectrum:}

The UV-VIS spectrum of m-CHF-I resin was recorded by instrument Shimadzu UV-VISNIR spectrophotometer Model No.1601. The spectrum so obtained is shown in fig. 1. The 
peak at $284.16 \mathrm{~nm}$ assigned to $\mathrm{n}-\pi^{*}$ transition due to phenolic group. Absorption at 252.6 $\mathrm{nm}$ was assigned to $\pi-\pi^{*}$ due to aromatic ring. The absorption at $236.86 \mathrm{~nm}$ was assigned to $n-\sigma^{*}$ which was support to ether linkages in structure of resin in fig. 4.

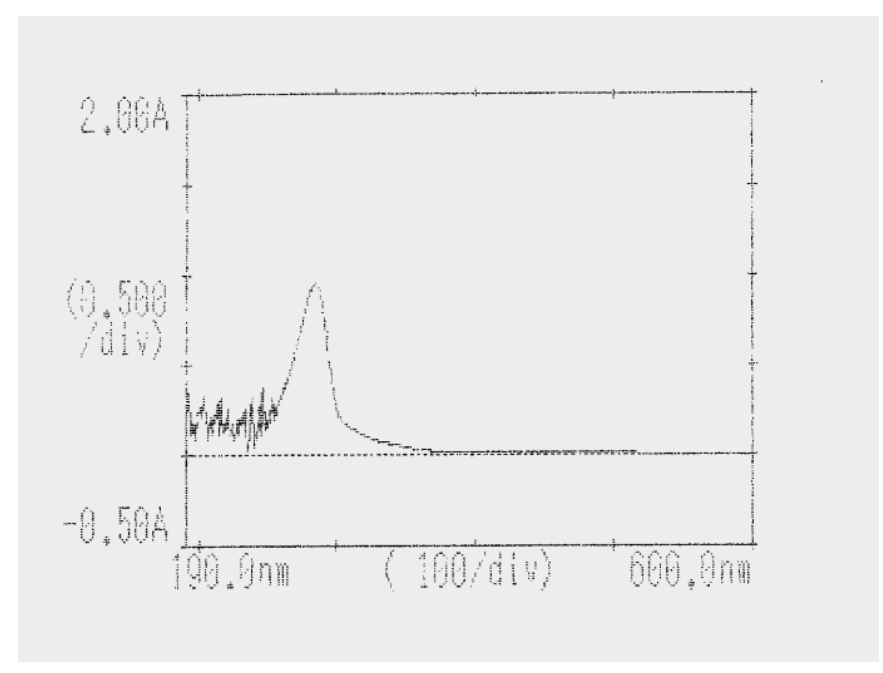

Figure 1: UV-VIS spectra of m-CHF-I.

\section{FTIR and NMR Data of $m-C H F-I$ :}

The IR spectra (fig. 2) of m-CHF-I terpolymeric resin was carried out at Pharmacy Department, Mahatma Jyotiba Phule Campus, R. T. M. Nagpur University and NMR spectra (fig. 3) of m-CHF-I resin was carried out at Sophisticated Analytical Instrumental Facility(SAIF) Punjab University, Chandigarh which is presented in Table3.

Table 3: IR and NMR spectra of m-CHF-I resin ${ }^{26-32}$.

\begin{tabular}{|c|c|c|c|}
\hline $\begin{array}{c}\text { IR (wave number in } \\
\mathrm{cm}^{-1} \text { ) }\end{array}$ & $\begin{array}{c}\text { Nature of fragment } \\
\text { assigned }\end{array}$ & $\delta$ in ppm & $\begin{array}{c}\text { Nature of fragment } \\
\text { assigned }\end{array}$ \\
\hline $3300-3350$ & -NH- & $\begin{array}{l}2.23- \\
2.27\end{array}$ & $\mathrm{CH}_{2}$-NH-CH $\mathrm{CH}_{2}$ Moiety \\
\hline 3602 & -OH (Phenolic) & $3.7-4.0$ & -NH- Bridges \\
\hline 1595 & Aromatic $\mathrm{C}=\mathrm{C}$ str. & 4.7 & Ar-OH Moiety \\
\hline 1358 & -C-N-str. & 2.3 & $\mathrm{Ar}-\mathrm{CH}_{3}$ Moiety \\
\hline $1100-1200$ & C-O-C (Ether linkage) & $6.7-7.9$ & Ar-H (unsymm. pattern) \\
\hline 1124(m), 915(w) & N-C-N def. & 2.7 & $\mathrm{Ar}-\mathrm{CH}_{2-}^{-}$ \\
\hline $1022(\mathrm{w}), 850(\mathrm{w})$ & C-N-C def. & & \\
\hline
\end{tabular}

According to data obtain in physicochemical methods, the tentative structure terpolymeric resin was assigned as shown in fig. 4. 


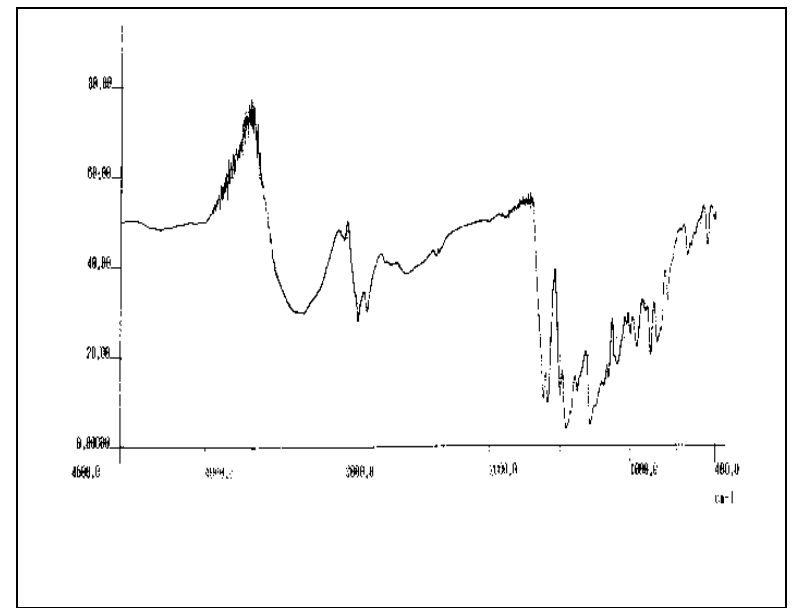

Figure 2: IR spectra of m-CHF-I resin.

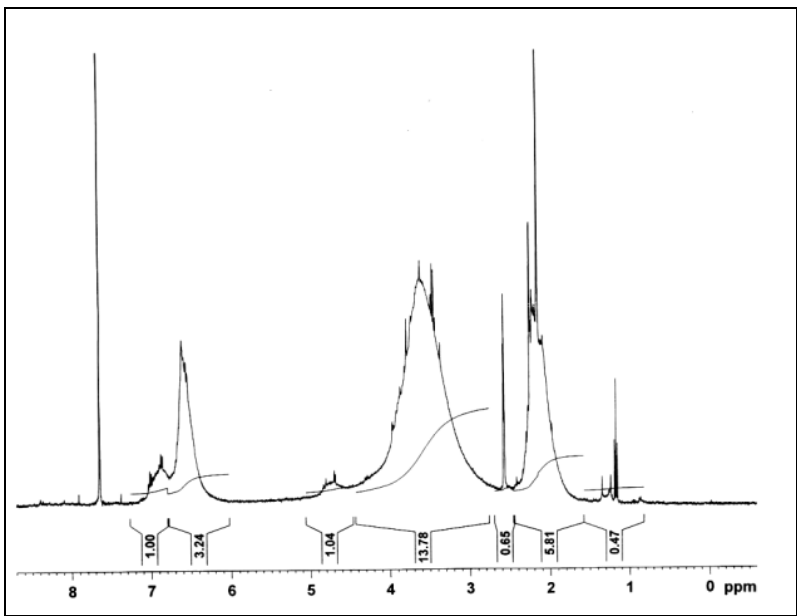

Figure 3: NMR spectra of m-CHF-I resin.<smiles></smiles>

Figure 4: Tentative structure of m-CHF-I. 


\section{Thermogravimetric Analysis:}

The thermogram of m-CHF-I terpolymer resin as shown in fig. 5, was recorded at Dept. of Material Science, VNIT Nagpur using Perkin Elmer Diamond TGA/DTA analyzer in argon environment. The polymeric sample was allowed to heat upto $950{ }^{\circ} \mathrm{C}$. The thermogram reveals that initial weight loss up to $150^{\circ} \mathrm{C}$ due to loss of water. The decomposition of resin between 410 to $485^{\circ} \mathrm{C}$ was studied. FC and SW plots are shown in fig. 6a and fig. 6b respectively. The order of decomposition was found to be zero order as determined by FC method which was further confirmed by SW method. Thermokinetic parameters are tabulated in Table 4.

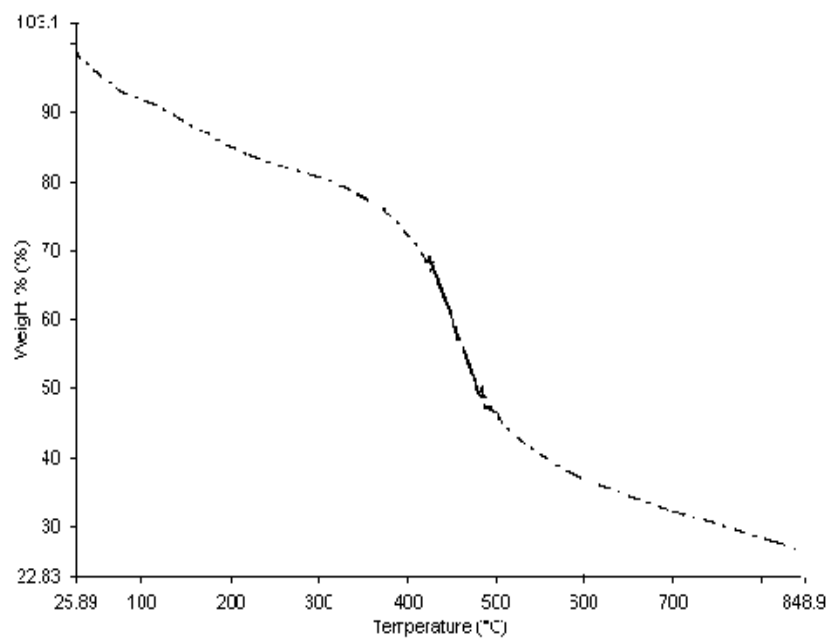

Figure 5: Thermogram of $\mathrm{m}-\mathrm{CHF}-\mathrm{I}$ resin.

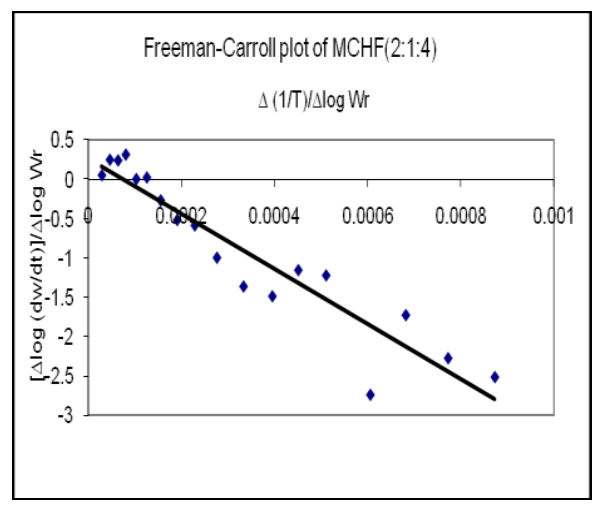

Figure 6: (a) FC plot.

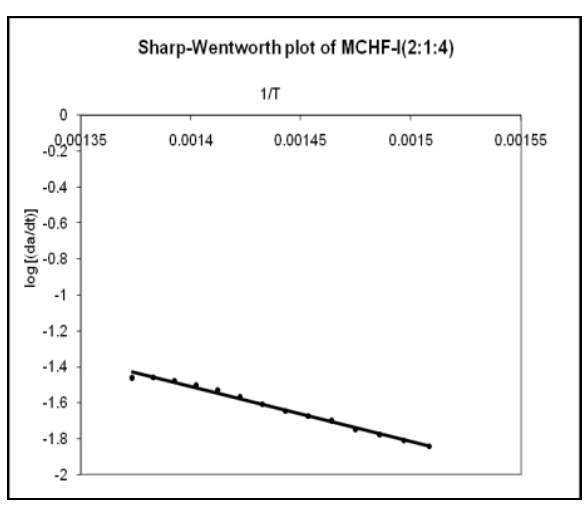

b) SW plot. 
Table 4: Thermokinetic parameters of m-CHF-I terpoymeric resin.

\begin{tabular}{|c|c|c|c|c|c|}
\hline $\begin{array}{l}\text { m-CHF-I } \\
\text { terpolymeric } \\
\text { resin }\end{array}$ & 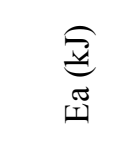 & $\underset{\mho}{\stackrel{\overbrace{}}{(\Xi}}$ & 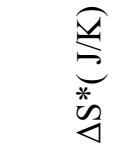 & \begin{tabular}{l}
$\underset{\nexists y}{*}$ \\
\multirow{y}{*}{}
\end{tabular} & $\operatorname{Order}(\mathrm{n})$ \\
\hline FC method & 58.56 & 3954 & -179.61 & 190.1 & \multirow[b]{2}{*}{$0.07 \sim 0.0$} \\
\hline SW method & 58.56 & 5901 & -176.28 & 187.66 & \\
\hline
\end{tabular}

\section{Conclusion}

The elemental analysis and spectral studies such as UV-VIS, IR, NMR data is in good agreement with assigned tentative structure of m-CHF-I terpolymeric resin. The activation energies, entropy and free energy of zero order degradation are determined by FreemanCarroll and Sharp-Wentworth methods are in good agreement. Low value of frequency factor and entropy indicate the slow degradation of resin. The high value of energy of activation relative to thermal energy suggests that the m-CHF-I resin is thermally stable below $400^{\circ} \mathrm{C}$.

\section{Acknowledgment}

Authors are grateful to Dr. M. T. Bharambe, Director, Institute of Science, Nagpur and Dr. R. H. Limsay, Head, department of chemistry for providing available facilities.

\section{References}

1. Khare P K, Pandey R K and Jain P L, Bull. Mater. Sci., 1999, 22 (60), 1003.

2. Learmonth G S and Marriott A G, Europ. Polym. J., 1969, 5(4), 441.

3. Bhave N S and Aswar A S, Asian J. Chem., 1992, 4(1), 65.

4. Jaykumar R and Nanjudan S, J. Polym. Sci., 2004 Part-A, 42, 1809.

5. Lizymol P P, J. Appl. Polym. Mater., 2004, 21, 71.

6. Mythili C V, Retna A M And Gopalkrishnan S, Bull. Mater. Sci., 2004, 27(3), 235.

7. Raval D K, Narola B N and Patel A J, Iranian Polym. J, 2005, 14 (9), 775.

8. Shah B A, Shah A V and Shah D M, Iranian Polym. J., 2006, 15(10), 809.

9. Shah B A, Shah A V and Bhatt R R, Iranian Polym.J., 2007, 16 (3), 173.

10. Conley R T, Am. Chem. Soc. Div. Org. Plat. Chem. Pap., 1966, 26, 138.

11. Hiwase V V, Kalambe A B, Umare S S, Raut R D, proceedings of NCATMSA, Arts, Commerce \& Science College, Arvi, 2011, pp.240-246.

12. Gurnule W B, Paliwal L J and Juneja H D, Oriental Journal of Chemistry 1999, 15(2) 283.

13. Aswar A S and Munshi K N, J. Indian Chem Soc, 1992, 69, 544.

14. Masram D T, Bhave N S and Kariya K P, E-journal of chemistry 2010,7(2), 564.

15. Freeman E S and Carroll B , J. Physc. Chem., 1958, 62, 394.

16. Masram D T, E. Journal of Chemistry 2009, 6(3), 830.

17. Sharp J H And Wentworth S A, Anal. Chem., 1969, 41 (14), 2060. 
18. Singru R N, Khati V A, Gurnule W B , Zade A B, Dontulwar J R Anal. Bioanal Electrochem., 2011, 3(1), 67.

19. Mallikarjun K G, E. Journal of chemistry 2004, 1(2),105.

20. Chaterjee S K, J. Polym. Sci., Part-I , 8, $1970,1299$.

21. Pal T K and Kharat R B, Ind. J. Chem. 1989, 28A, 55.

22. Patel J S, Sutaria D H and Patel M M, High Perform. Polym., 1994 6(3), 201.

23. Hiwase V V, Kalambe A B, Khedkar K M, Deosarkar S D, E-Journal of chemistry, 2010, 7(1), 287-294.

24. Gurnule W B, Juneja H D and Paliwal L J, React. Funct. Polym., 2005, 50 (2),95.

25. Singru R N, Zade A B and Gurnule W B, E-Journal of chemistry, 2009, 6(S1), S 171S182.

26. Dyer J R Application of Absorption Spectroscopy of Organic Compounds, 2nd Ed., New Delhi, 1972, 33-37.

27. Silverstein R M and Webster F X Spect. Identification of Org. Compd. $6^{\text {th }}$ edn. John Willey New York 1998, 144.

28. Silverstein, R M, Bassler G C Spectrometric Identification of Organic Compounds, $2^{\text {nd }}$ Edn. John Wiley and Sons Inc., New York, 1967, 80-67.

29. Ballamy I J, The IR Spectroscopy of Complex Molecules; John Wiley and Sons. Inc., 1958, 142-60.

30. Morrison R T and Boyd R N, Org. Chem. $6^{\text {th }}$ Edn. Prentice Hall India Pvt. Ltd., 2004,710.

31. Field L D , Sternell S and Kalman J R Org. Struct from spectra, John Willey and Sons, New York, $2^{\text {nd }}$ Edn. 1969, 29.

32. Kalsi P S Spectroscopy of Organic Compounds $6^{\text {th }}$ Edn. New Age International Publishers 2004, pp. 9-20. 


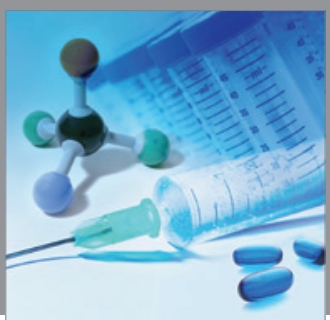

International Journal of

Medicinal Chemistry

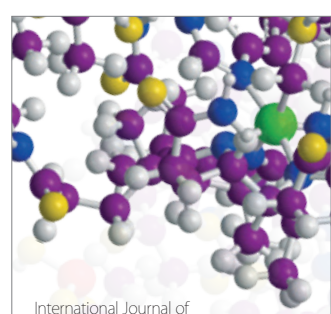

Carbohydrate Chemistry

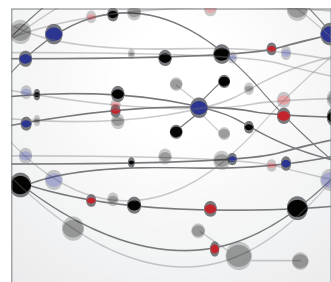

The Scientific World Journal
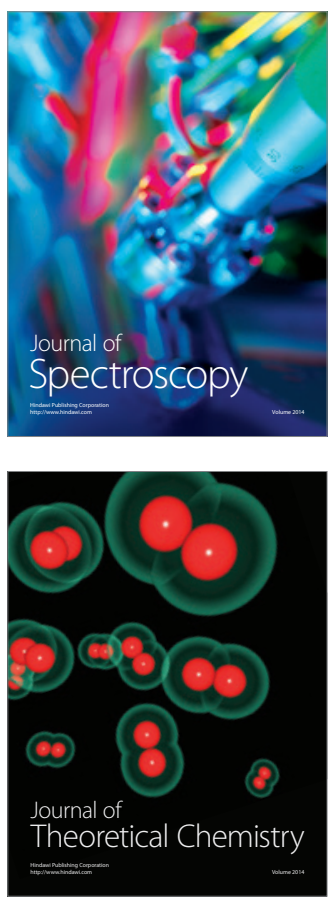
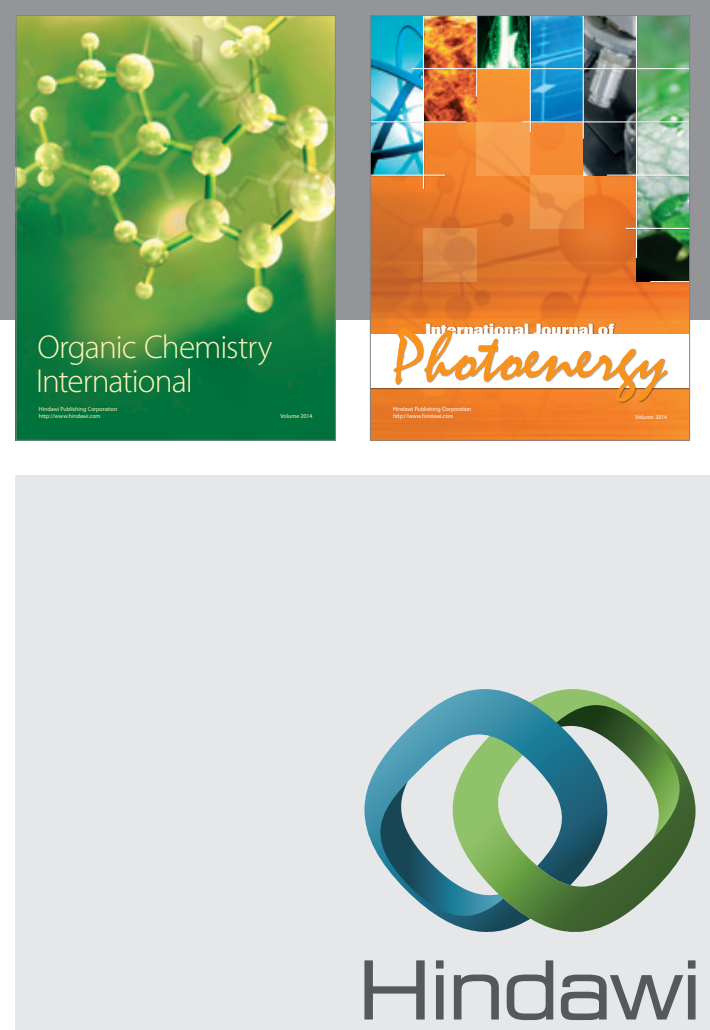

Submit your manuscripts at

http://www.hindawi.com
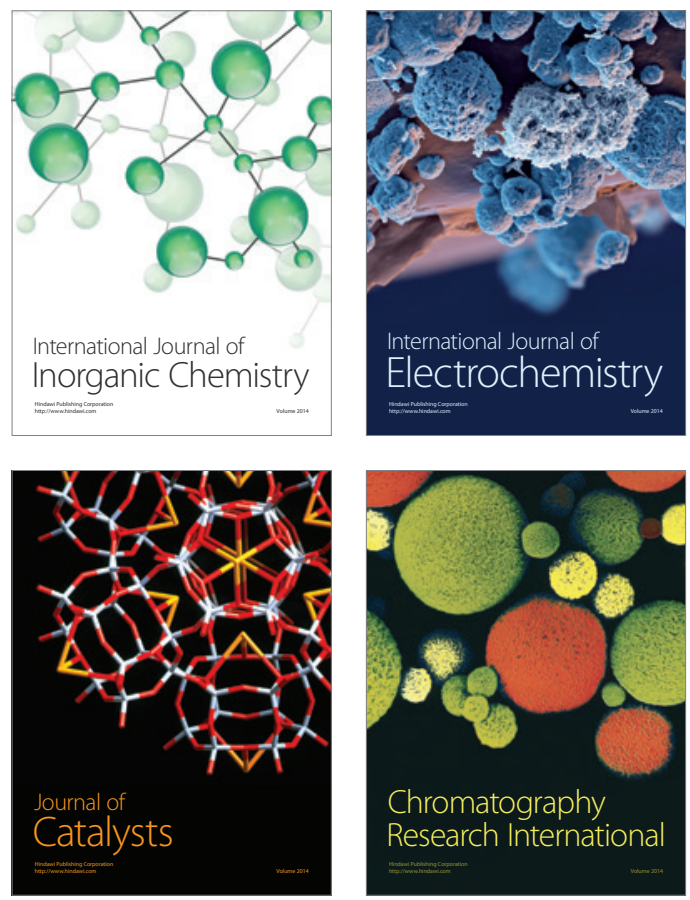
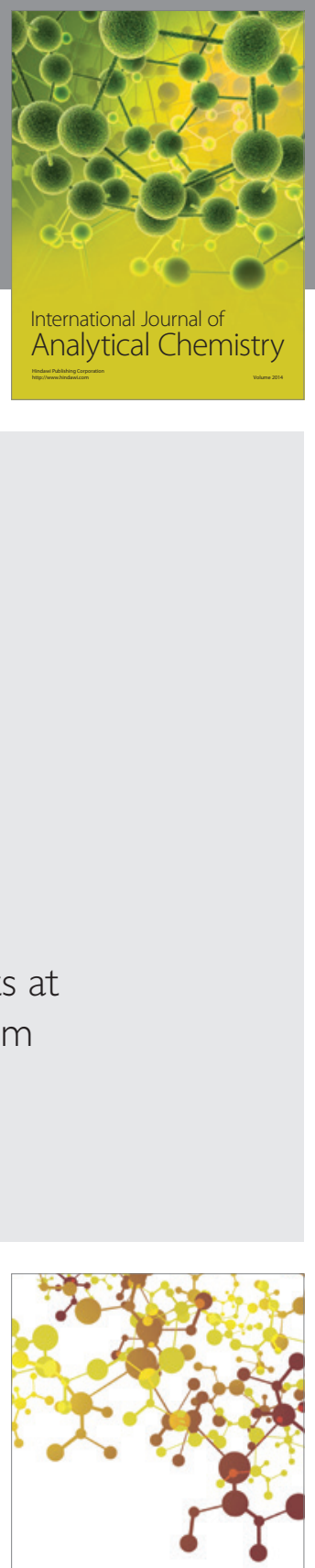

Journal of

Applied Chemistry
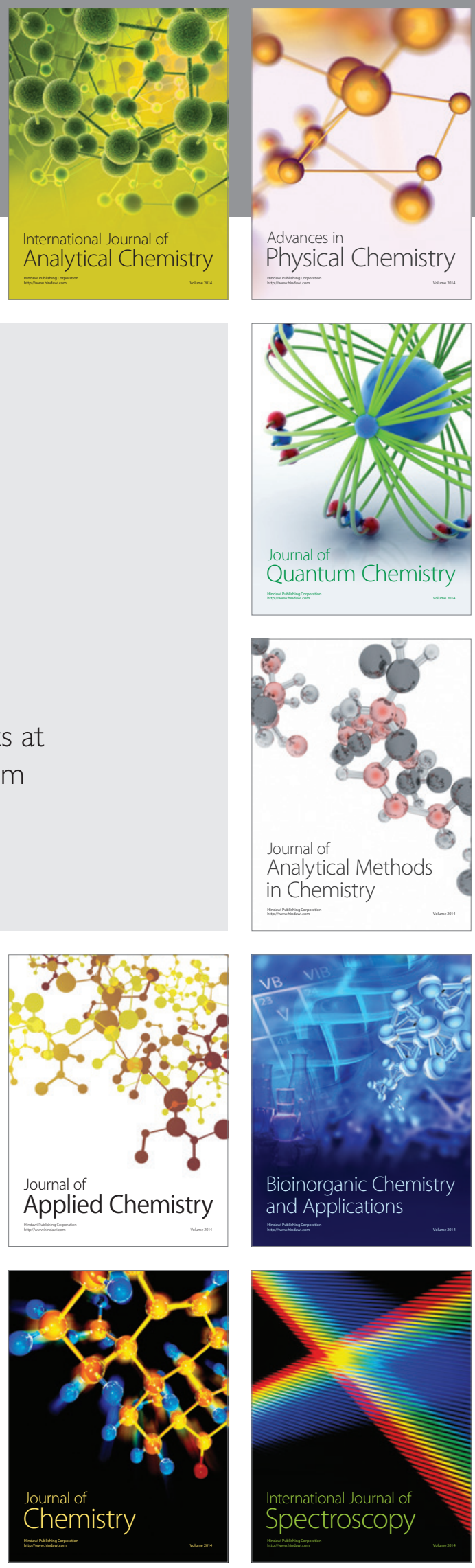